\title{
DIREITO PENAL DA CULPA COMO CENTRO DO SISTEMA JURIDICO-PENAL
}

\section{Prof. José Salgado Martins}

Nesta quadra final do nosso século, tão cheia de radicais e agudas contradições, quando se distorcem e se truncam os conceitos mais claros e fundamentais, principalmente no campo da Filosofia Moral e das ciências do homem, a relevância do tema se sobrepõe naturalmente a qualquer outro. Constitui, ele, o plexo nervoso que aciona e comanda o próprio coração do Direito Penal.

Só depois de muitas vicissitudes, o Direito Penal experimentou a nostalgia do brilho e da grandeza que alcançara no período clássico.

A concepção então dominante sobre o universo e o homem, baseada na teologia cristã, considerava o homem e o universo como submetidos a uma lei de harmonia universal, cuja fonte se achava na ordem criada pela Suprema Inteligência.

$\mathrm{O}$ direito de punir que pertence à autoridade civil, afirmava Carrara, ${ }^{1}$ emana da lei eterna da ordem aplicada à humanidade, o que importa dizer que ela emana da lei natural. "Esta lei eterna, absoluta, revelada por Deus à razão humana, é formada pelo conjunto de princípios que regem a conduta exterior dos homens. A lei moral que é um dos aspectos da lei eterna da ordem, assume o caráter de lei jurídica, quando impõe deveres e concede direitos ao homem para que ele possa cumprir o seu destino sobre a terra. Do livre exercício desses direitos e correlativamente da obediência ao dever de os respeitar nasce a ordem moral exterior colimada pela lei natural. Destinado, pela lei de sua criação, a exercer livremente a sua atividade nos limites do respeito à liberdade de seus semelhantes, o homem está colocado ab aeterno sob o império da lei moral que rege, ao mesmo tempo, os seus direitos e os seus deveres".

Ao homem dotado de inteligência e de vontade livre se

1. Programa, 590 a 610 
reconhecia a faculdade de escolha entre o bem e o mal, entre a virtude e o pecado, entre a ação lícita e o crime. E, consequentemente, a sua responsabilidade pelos atos praticados era simples corolário da liberdade de vontade, de seu livre-arbítrio.

A essa concepção correspondeu um Direito Penal que a si mesmo traçava os lindes de sua jurisdição prática e científica.

O direito é a liberdade, proclamava Carrara ${ }^{2}$. E acrescentava: "A ciência criminal bem compreendida é, pois, o supremo código da liberdade, que tem por objeto o de subtrair, ao homem, da tirania dos outros e o de ajudá-lo a libertar-se da tirania de si mesmo e de suas próprias paixões".

Ao positivismo científico do século XIX pareceu que essa visão quase paradisíaca do homem não se coadunava com a miséria da criatura humana, simples joguete de fôrças naturais mecânicamente determinadas.

As ciências desenvolvidas naquele clima saturado de naturalismo construiram uma imagem do ser do homem governado pelo determinismo fisio-psicológico de suas ações.

A psicologia, de fundamento fisiológico, a neuro-psicologia, a antropologia constitucionalista, a psicanálise, por último, considerando a dinâmica da vida psíquica dominada pelos conflitos inconscientes, arrastando o homem, muitas vezes, a ações incoercíveis, fizeram "tabula raza" da autonomia e da liberdade do espírito humano, encadeado a uma rede de causas e efeitos.

Protegidos pelo fogo das baterias naturalistas, os adeptos da ciência nova atacaram a fortaleza clássica, tão bela na pureza de suas linhas, desprendendo-se, no dizer de Soler ${ }^{3}$, da superfície carcomida dos muros, das colunas destroncadas e dos áticos em ruínas, uma harmonia recôndita, uma proporção pitagórica que anima as partes com o anúncio da sujeição a uma estrutura.

Sobreveio a idade das fórmulas e das leis. A lei da saturação criminal de Ferri é um modelo da ingenuidade científica, fruto daquele século de exacerbado naturalismo. As categorias dos criminosos, outro. A defesa social levada ao exagero do utilitarismo, desprezando a luta heróica do Direito Penal em trazer, dos tempos sombrios do puro objetivismo, a responsabilidade, para o conteúdo subjetivo e ético que lhe é consubstancial. A noção da culpa destituída de qualquer significação teleológica. O conceito de perigosida-

2. Préf́cio à 5.a edicáno do Prog. del Corso dl Diritto Criminale. de inspirado tão somente na materialidade do dano efetivo, potencial ou possível.

Foi necessário que recaíssemos num período de terror já na primeira metade deste século, que se voltase na justiça penal aos processos de coação e de tortura, que a lei penal voltasse a ser a vontade do tirano, que a pessoa fosse oprimida e espezinhada pelo Estado totalitário, para que a natureza moral do homem, a autonomia do espírito humano, a dignidade da pessoa tornassem a ser o fulcro pelo qual o Direito Penal deve filtrar os valores ético-sociais a serem protegidos e assegurados.

Mercê de Deus, os mitos científicos do século XIX foram, pouco a pouco, abalados de seu sólio. Dentro do próprio campo positivista já se recuava das posições rigidamente ortodoxas.

Spencer 4 advertira que o conhecimento positivo não preenche e não poderá jamais preencher o inteiro domínio do pensamento possível. Ao termo da descoberta mais avançada, uma questão se levanta e se levantará sempre: O que há depois? Assim como é impossível conceber um limite ao espaço e excluir a idéia de que há ainda um espaco além desse limite, não podemos conceber uma explicação tão radical para excluir a questão.

Bergson $^{5}$ vislumbrava que o espírito humano seria capaz de, através do conhecimento intuitivo, seguir o real em todas as suas sinuosidades e adotar o mesmo movimento da vida no interior das coisas. A ciência e a metafísica se resumem, pois, na intuição.

Dilthey ${ }^{6}$ mostra que a vida humana, com toda a riqueza de sua liberdade, pode ser objeto de ciência, mas ciência de um tipo diferente das ciências que cuidam dos fenômenos naturais.

A esse movimento de idéias superadoras dos quadros do cientificismo positivista, acrescentou-se a múltipla corrente do existencialismo moderno que, não obstante certos desgarres materialistas, põe uma nova ênfase à posiç̃a do homem no universo, realçando ser ele o portador, por excelência, dos valores que se objetivam nos bens da cultura e da civilização.

Max Scheler " coloca o homem numa posição proeminente sobre todas as coisas do Cosmos, ser superior a si mesmo e ao mundo, capaz de ironia e de humor - que im-

4. Les Premieres Principes, p. 13.
5. Int. à Metaphysique, ns. 1603/03.

6. Int. a las Ciencias del Espiritu, Fondo de Cultura Economica. México, 1949 
plicam sempre uma elevacão sobre a própria existência. O homem é o único ser que pode transcender a si mesmo converter todas as coisas, e entre elas também a si mesmo, como objeto de seu conhecimento.

Ao conceito de natureza imutável em sua essência se opõe a concepção de uma essência dinâmica e autocriadora no homem a se projetar na sua dimensão histórica. "Segundo essa visão existencialista, oposta à imagem de uma ontologia existencialista, o homem cria o mundo no próprio ato em que ele se fundamenta como liberdade no seio da existência. A atividade autocriadora se revela assim como substância última com que se constituem a existência e o mundo". ${ }^{8}$

No meio dessas correntes de idéias que tornam tão atraente e vivo o panorama intelectual dos tempos modernos, alça-se singularmente a Filosofia dos Valores, ou Axiologia, em cuja órbita gravita o Direito.

O Direito Penal, de todos os ramos jurídicos, é aquele em que mais profundo e mais intenso se manifesta o caráter axiológico. Por isso a crise do Direito Penal, quando este parecia já estar vencido pelas ciências causal-explicativas do crime, era mais uma crise de superfície, que não afetara a sua natureza, mas apenas abalara os marcos que assinalam o seu território autônomo, invadido, às vezes, pelo positivismo naturalista, no afã de subverter as peculiaridades de cada área de conhecimento. $\mathbf{E}$ isso porque, como acentua Radbruch, "não pode haver uma justa visão de qualquer obra ou produto humano, abstraindo do fim para que se serve e do seu valor". "Uma consideracão cega aos fins, ou cega aos valores, é pois aqui inadmissível e assim também a respeito do Direito ou de qualquer fenômeno jurídico. Do mesmo modo, por exemplo, uma ciência natural do crime, como pretendeu construí-la a Antropologia Criminal, só é possí vel depois de se ter substituído a um conceito de crime, referido a valores jurídicos, um conceito naturalístico de crime. Seria, com efeito, um milagre extraordinário - produto de uma espécie de harmonia pré-estabelecida entre dois modos totalmente diversos de contemplar a realidade, que ninguém suspeitaria possível - se um conceito formado com referên cia a valores como o de direito $\mathrm{cu}$ de crime, pudesse coincidir com um conceito naturalístico obtido através de uma contemplação valorativa (wertblind) das coisas". 9

8. Batista Machado, Antropologia, Existencialismo e Direito, p. 28
9. Filosofia do Direito, trad. de Cabral de Moncada, p. 12.
Eduardo Correa ${ }^{10}$, o eminente professor da Universidade de Coimbra, explicando o sentido que o orientou na elaboraç̃o do seu projeto de Código Penal português, e referindo-se aos perigos de equacionar o direito criminal no quadro de uma defesa social do tipo naturalístico, pela via da prevenção especial, tal como entendiam os positivistas, assinala, com inteira propriedade:

"Considerada, na verdade, a defesa da sociedade, relativamente ao criminoso e à sua perigosidade, num puro plano naturalístico, como uma defesa de "um organismo vivo em face do micróbio que o mina", fica aberto o caminho que conduz a olhar o criminoso, definido em função da sua te mibilitá, como um "inimigo" que importa por fora de combate, mesmo pela via simples e segura de sua definitiva segregação ou destruição".

"E, dado, por um lado, que o combate naturalístico à perigosidade do delinquente deve logicamente estender-se às suas causas e, por outro, que a determinação da perigosidade criminal se terá de fazer em função de interesses que a lei arbitrariamente fixa, os limites da defesa social virão a perder toda a fixidez e deixar-se-á o indivíduo inerme em face do poder".

"Da realidade deste risco dá, aliás, a história, recentes exemplos flagrantes, que bem mostram a que extremos e abusos pode conduzir a lógica do cientismo dos positivistas e "modernos". E a tal ponto que a chamada "Nova Defesa Social" (refere-se ao movimento francês "La Defense Social Nouvelle" de que Marc Ancel é ilustre epígono) se apressou a quebrar a força do silogismo naturalista, repudiando resolutamente o "determinismo positivista", admitindo uma larga margem de liberdade para o ser humano, restaurando as noções de livre arbítrio e de responsabilidade e condenando um direito orientado pelo puro pensamento defensista, que o desliga das obrigações morais e não considera a especial posição do homem no universo, a sua particularidade de "ser pessoa" e a sua dignidade própria".

"Nesta verdadeira liquidação do positivismo estará, quanto a nós, o altíssimo mérito e virtude de tão vasto e frutuoso movimento, que só não logra a sua plenitude construtiva porque, encadeado pela idéia utilitária de defender a sociedade, esquece-se que essa defesa envolve sempre uma intromissão na liberdade e na autonomia da pessoa humana e que, portanto, só a partir desta, da sua culpa ética, se

10. Código Penal - Proj. da Parte Geral - Separata do Ministério da Justiça de
Portugal, 1963, n. 127, p. 13 e 14. 
pode e deve alicerçar a reprovação, expiação ou retribuição $\epsilon$, portanto, a pena".

Vencido o erro positivista, delimitado o terreno científico em que se deve conter a investigação do fenômeno criminal, de um lado, e a valoração jurídica do comportamento humano, de outro, superado o período conflitual das escolas, cumpre aos penalistas na árdua tarefa de recompor os quadros penais à luz de uma filosofia dos valores, com base na tradição de nossa cultura, incorporando tudo quanto há de valioso e perdurável na nossa experiência histórico-cultural, com uma prospecção para o futuro dentro do contexto das novas realidades do mundo moderno.

$\mathbf{E}$ há de ser pela doutrina da culpa, cuja maior penetração na esfera jurídico-punitiva, como observa o prof. Everardo da Cunha Luna, ${ }^{11}$ significa maior aproximação do Direito Penal à natureza humana, e determinando o seu conteúdo onto-axiológico, no plano da normativdade jurídica concreta, que o Direito Penal reflorescerá como expressão de um novo humanismo jurídico.

Para se colocar o problema em termos de análise, convém partir da posição entre Moral e Direito, suas distinções e seus contatos.

Miguel Reale, ${ }^{12}$ com a visão de filósofo e jurista, estudando a experiência moral e a experiência jurídica, pondera "que por mais que se renovem os horizontes da experiência Social, o Direito e a Moral continuam sendo realidades históricas inamovíveis que ora se correlacionam, ora se antagonizam, ora tendem a se contrapor, ora a se confundir, ressurgindo sempre a intuição ou a consciência crítica de que ambos se distinguem e se correlacionam em função de algo conatural ao ser do homem e às estruturas da convivência social". É a essa luz, acrescenta Reale, que, no e do plano mesmo da experiência histórica, surge um problema essencial, o das "condições transcedentais", que fazem do direito e da moral duas formas de vida, distintas mas complementares, não havendo incompatibilidade lógica em se reconhecerem, concomitantemente, a universalidade de sua correlação e a sua condicionalidade histórica".

Parece-nos ainda válido o pensamento de Pufendorf no sentido de distinguir, mas não separar, a ética e o direito, reconhecendo que ambos se entrelaçam em suas raizes profundas.

11. A Personalidade do criminoso e a caracterologia de Heymans e Wiersma, in Es-

12. O Direito como Experiência, p. 203 .
Ao escrever o apêndice intitulado "De Officio hominis et Civis" à sua obra principal "De Jure naturae et gentium", Samuel Pufendorf, que sensível influência exerceu sobre os convencionais de Filadélfia, e, assim, indiretamente, sobre os nossos legisladores constituintes de 1891, respondendo às críticas feitas ao seu pensamento, principalmente em relação a Hobbes, acentua a diferença entre os conceitos de coação (Zwang) e obrigação (Verpflichtung). Ambos implicam uma influência sobre o sujeito por meio do temor: a coação, porém, intimida a vontade somente de uma forma exterior, enquanto que o dever afeta a vontade moralmente e a cerca internamente com um sentido especial, mediante o qual ela é forçada a reprimir-se e a considerar-se merecedora de um mal, quando, procedendo como procedera, não está conforme como o prescrito pela norma. O dever, à luz do pensamento de Pufendorf, compreenderia aqueles fundamentos que atingem a consciência do homem de tal forma que possa reconhecer, valendo-se do seu próprio juízo, de que resistir não seria correto, isto é, adequado ao direito. Polemizando, depois, com Valentim Alberti, em 1678, que o censurara de, fazendo a diferenciação entre ética e direito, esquecer que o significado das açõs se apóia mais em sua bondade intríseca do que em sua manifestação exterior, Pufendorf responde que o seu pensamento não nega aquela perspectiva moral a que alude Alberti e sustenta que, de modo algum, os motivos anímicos interiores seriam completamente irrelevantes, embora o direito se ocupe, em sua maior parte, da conformação do aspecto exterior das ações dos homens.

O problema da culpa, ontológica e axiologicamente, pode e deve ser colocado em perspectiva ética. E é nessa perspectiva que se ilumina todo o seu significado, indicando que no direito penal o retorno à subjetividade representa a mais rica direção, não só no sentido da justificação da pena, teleologicamente considerada, como da própria defesa social pela instauração dos valores éticos na convivência social, de mođo a fortalecer os motivos de inibição ao crime.

Antes de examinar o princípio "nullum crimen sine culpa" no Código de 1969, vejamos, segundo a moderna teoria penal, o conceito da culpa e as implicacões fundamentais que dele decorrem, mais restritas ou mais extensas, conforme o conteúdo e os elementos que o constituem.

O núcleo da culpa repousa sobre um juízo de valor acerca do fato tipificado pela norma penal. O juízo de reprovação social, que constitui a censurabilidade do fato, e que levou, primeiro, o legislador a incluí-lo no elenco dos 
fatos puníveis e, depois, levou o juiz a reconhecer sua injuricidade concreta, é vivenciado pelo autor do fato no momento em que age em harmonia ou em oposição à norma penal. A culpabilidade é um momento posterior à injuricidade. Mas ambas se implicam. É nessa vivência da injuricidade do fato que vai formar-se a culpabilidade. Maurach ${ }^{13}$ parece haver compreendido isto, quando escreve que o juízo de desvalor estendido, do ato destituído de valor, ao autor se designará como culpabilidade jurídico-penal ou, abreviadamente, culpabilidade.

Surge um primeiro problema, relacionado a este juizo de valor, qual seja se a culpabilidade é especificamente jurídica e, sob certas circunstâncias, exclusivamente de direito penal, ou se pode resultar de regras morais ou de representações valorativas extra-penais.

Sabe-se que a noção de culpabilidade no direito penal não coincide com a noção de culpa ou culpabilidade no direito civil. A culpa no direito civil tem contornos distintos. No direito administrativo exacerba-se ainda mais o caráter objetivo da culpa, podendo-se falar de uma culpa inteiramente impessoal (ou talvez se pudesse dizer anônima) que é chamada culpa do serviço representada pela omissão de providências ou normas de que vem a resultar o dano ou a lesão ao direito. A distinção entre várias espécies jurídicas de culpa não invalida, porém, o conceito de que o ilícito penal não se esgota apenas no quadro do direito penal. A plenitude do seu conceito só pode ser extraída de todo o sistema jurídico vigente.

Apoderar-se de uma coisa só poderá constituir em determinadas circunstâncias ilícito penal, se a ação correspondente for praticada pelo agente, sem qualquer direito. E a noção, acerca dessa ilegitimidade ou injuricidade de que a ação se revestiu, só pode completar-se em muitas hipóteses através de valorações que transcendem o direito penal e vão projetar-se no campo geral do ordenamento jurídico e mesmo no campo moral de que se nutre o sistema.

$\mathrm{Na}$ antiga doutrina, a culpabilidade se apresentava como simples nexo psicológico entre o autor e o resultado típico. Indagava-se tão só se o resultado se constituiria como efeito da ação praticada, sendo esta voluntária ou negligentemente causada. Não entrava em exame o ânimo do autor, a consciência sobre o conhecimento da iliceidade da ação. A culpa se expressava sob duas formas - o dolo e

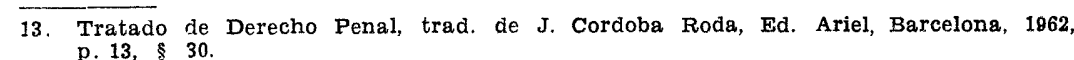

a culpa stricto sensu - cuja distincão se baseava tão somente no comportamento da vontade: o dolo resultava da adesão da vontade ao resultado; a culpa na inércia da vontade, ou na simples possibilidacie de previsão de um resultado que não fora querido pelo agente.

Tấo só pelo predomínio das ciências da natureza no direito penal - afirma Maurach - pode explicar-se que durante tão longo tempo se contentara a dogmática com a simples possibilidade de derivação, das duas espécies de culpabilidade, da característica comum constituída pela relação psicológica com o resultado.

A insuficiência da noção puramente psicológica criava verdadeiros impasses ao direito penal. E por ela penetrava a. responsabilidade objetiva. O problema do erro de direito a do erro de fato se magnificava. Sem solução, a não ser pela porta ampla do versari in re illicita, as hipóteses de resultados excedentes à vontade explícita do agente, mas contidos na cadeia causal voluntária com que a ação se instaurara. Daí se haver evoluído para a noção normativa ou ética đa culpa, em que a consciência da llicitude começa a aparecer como exigência contrastante da própria injuricidade objetiva. Assim como a injuricidade envolucra um juízo de valor que pode ser reproduzido pelo autor do fato, a culpabilidade é envolvida pelo mesmo juízo de valor no qual a injuricidade aparece como algo que se incorpora à subjetividade do agente e vai produzir a adequação ou inaciequação de seu comportamento à norma penal. A presença da consciência da ilicitude será exigência então da plenitude do elemento subjetivo. A falta da consciência da ilicitude poderá excluí-lo, salvo naqueles casos em que aquela ausência resultar de uma "culpa da personalidade". "Em que consista, porém, este comportamento que faz o seu agente censurável pela sua personalidade, pelo seu caráter ou pelas suas tendências, constitui, segundo Eduardo Correia, um problema para o qual se encontram as mais variadas respostas.

O eminente penalista português ${ }^{14}$ ensaia esta solução: "Simplesmente, para o plano do direito e especialmente para o plano do direito criminal, o verdadeiro caminho parece estar em fazê-lo corresponder a uma omissão - e a uma omissão permanente da vida do delinquente - do cumprimento do dever de orientar a formação ou a preparação da sua perso-

14. Exposição de Motivos do Proj. da Parte Geral do Código Penal, p. 25-26. 
nalidade de modo a torná-la apta a respeitar os valores jurídico-criminais. Dito por outras palavras: na medida em que o direito criminal afirma certos valores ou bens jurídicos, cria para os seus destinatários o dever de formar, ou ao menos preparar, a sua personalidade, de modo a que, na sua atuação na vida, se não ponham em conflito com aqueles valores ou interesses. Violando este dever constitui-se o delinquente $\in \mathrm{m}$ culpa pela formação ou não preparação conveniente da sua personalidade".

A concepção normativa da culpa não pode bastar-se observa Figueiredo Dias, com a referência desta ao evento exterior, antes tem de englobar também a sua referência à qualidade ilícita deste evento, que como tal tem de ser (ou ao menos "poder ser") apreendida ou valorada pelo agente, pelo que sempre exigirá uma consciência, atual ou potencial, da ilicitude.

Jorge Figueiredo Dias ${ }^{15}$ escreveu, como tese de doutoramento pela Faculdade de Direito de Coimbra, uma notável monografia que tem por núcleo a consciência da ilicitude em direito penal. Obra recente, aparecida em 1969, realiza, em suas quase 500 páginas, uma análise percuciente e sutil de todas as nuanças desse grave e transcendente problema penal.

Tratando-se desse aspecto da culpa que constitui o objeto da referida tese, não posso esquecer a excelência da contribuição do jovem penalista coimbrense que passou a ocupar posição singular na nossa ciência.

Precisamente sobre esse ponto capital - o da relevância ou irrelevância da consciência da ilicitude no contexto da culpa - Figueiredo Dias, em páginas densas, difíceis de resumir, pela riqueza e erudição de seu pensamento, discute as várias posições assumidas pela doutrina.

Traça este quadro que, nesta altura da explanação, pedimos vênia para reproduzir:

“a) Preferindo-se uma concepção "normativa" a uma meramente "psicológica" da culpa pode querer-se significar tão-só que o mesmo substrato que nesta última se considera - a relação psíquica, de certo tipo, entre o agente e o fato - deve agora ser visto sob a perspectiva da censura que o seu caráter desvalioso implica. Com este significado novo, porém, como exatamente nota Engisch, em nada se altera o conteúdo do con-

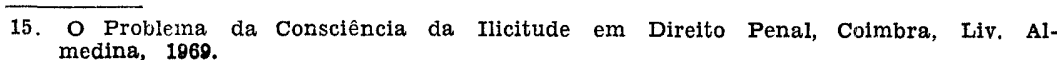

ceito psicológico de culpa, mas apenas muda a perspectiva metódica da sua consideração. $\mathrm{E}$ pois que, assim, ao conceito normativo de culpa se pode atribuir exatamente o mesmo conteúdo que ao conceito psicológico se conferia, é absolutamente impossível pretender que aquele impõe, ao contrário deste, a relevância da falta de consciência da ilicitude.

b) Com a afirmação da natureza normativa da culpa pode porém pretender-se algo mais, e exatamente o seguinte: que não haverá culpa onde não houver censurabilidade, mesmo que o substrato psíquico do tipo requerido se mantenha. A culpa exige, para além da comprovação cognoscitiva de um certo substrato psíquico, uma valoração pelo juiz daquele substrato; e seria justamente a consciência da ilicitude o elemento que, estando "para além" do substrato psicológico, determinaria em última análise o seu caráter censurável ou não censurável". (O grifo é nosso).

"Contudo, pode dar-se relevância à consciência da ilicitude e continuar a ter-se da culpa uma concepção psicológica - pelo menos e desde logo porque também um concreto ato de conhecimento ou de valoração é um ato psíquico. Diz-se, no entanto, que uma concepção verdadeiramente normativa da culpa não deve implicar a exigência de uma consciência atual da ilicitude, antes sim só a de uma consciência potencial que já nada tem que ver com processos psicológicos. E pretende-se que esta conclusão se evidenciará com uma clareza impressionante quando se reconheça que aquela concepção verdadeiramente normativa - tal como é defendida na Alemanha sobretudo por Welzel e Maurach, dentro de pressupostos que Arthur Kaufmann pôde crismar com razão de "racionalismo subjetivista" conduz a uma culpa como pura normatividade, como mero juízo de censura encabeçado no juiz e desprendido de todos os elementos (subjetivos) do substrato anímico e psicológico; pois a partir daqui seria irrecusável constituir a consciência potencial da ilicitude uma exigência do juízo de censura e, de nenhuma forma, um momento do substrato psicológico ao qual aquele juízo se dirige.

c) Diremos então que a concepção da culpa como mera normatividade impõe, sem mais, a relevância da consciência potencial da ilicitude? Do que fica dito já re- 
sulta que não. Culpa é censurabilidade. Mas o que é censurabilidade? Um ato no seu puro conteúdo externo-objetivo ou também na sua qualidade de desvalor jurídico? Uma certa conformação da vontade do seu autor? A perigosidade deste? Uma certa condução ou decisão da sua vida, uma defeituosa preparação ou formação da sua personalidade? Um certo caráter cu uma certa personalidade que no fato se exprimiu? depois: o que é censurabilidade? O atuar-se contra o dever no pressuposto do poder de agir de outra maneira? Ou simplesmente um certo sentido objetivo do desvalor jurídico? Eis só algumas das perguntas que de forma mais próxima condicionam a relevância ou irrelevância da consciência da ilicitude como problema de culpa e às quais se não pode r esponder com o simples apelo a uma concepção da culpa como pura normatividade ou censurabilidade". ${ }^{10}$

Da citação, deve ser ainda sublinhada a assertiva de que não basta, para afirmar a responsabilidade do agente pelo fato, o conhecimento ou a cognoscibilidade da ilicitude, exigindo-se também a "intervenção de um elemento especificamente normativo, qual é o da normalidade de motivação ou exigibilidade da conduta adequada ao dever". Pensa, contudo, Figueiredo Dias, que este elemento normativo exigibilidade de conduta adequada ao dever - é completamente independente de qualquer conhecimento ou cognoscibilidade da ilicitude e nada tem que ver, por conseguinte, com a relevância ou irrelevância desta para a culpa.

Compreende-se que assim seja, sob aquele aspecto. Não obstante o pleno conhecimento da iliceidade da ação realizada, a situação-limite que cerca e condiciona o agente não ihe permite, porém, comportamento adequado ao dever que seria a não realização da ação ilícita.

Então, a inexigibilidade de conduta diversa exclui a culpa, não obstante a consciência pessoal da ilicitude. Desaparece aí a culpa, pela não censurabilidade decorrente da inexigibilidade de outra conduta.

Ainda Figueiredo Dias fixa aspectos fundamentais dessa rica problemática da culpa, que merecem ser realçados.

Um deles é a distinção entre a consciência psicológica e a consciência ética.

$\mathrm{O}$ autor citado começa pondo este exemplo: "O automobilista que, seguindo na estrada em noite enevoada e sentindo um embate no veículo, continua o seu caminho 16. Ob. cit., p. $133,134,135$. porque supôs tratar-se de uma pedra ou de um animal quando na realidade se tratava de uma criança que ficou gravemente ferida - atua, relativamente ao fato tipicamente relevante (abandono do sinistrado), com falta de corhecimento de um elemento típico, com uma falta ao nível da sua consciência-psicológica que impede a consciência-ética de se orientar esclarecidamente para o problema de desvalor em causa (o do abandono). Já porém o automobilista que se dá conta que embateu numa criança e, vendo-a gravemente ferida, se não põe a questão do dever de a socorrer, ou se não julga veridicamente obrigado a fazê-lo e assim (v.g., para se não atrasar no caminho ou não manchar de sangue os estofos de seu carro) a abandona, possui ao nível da sua consciência-psicológica todos os elementos necessários para que a consciência-ética se ponha e decida corretamente o problema de desvalor em causa. Diremos nós, apesar disso, que o significado axiológico-normativo destas condutas é o mesmo para a culpa?"

"Uma resposta afirmativa só poderá ser dada se, também na segunda hipótese, encararmos a falta que aí se intromete no processo de motivação do agente pela perspectiva de uma falta de conhecimento, de um erro intelectual: dir-se-á então que o fundamento do fato reside, infelizmente para a criança sinistrada, em o agente não conhecer o artigo $60^{\circ}$ do Código da estrada, ou não o conhecer exatamente supondo, v.g., que ele só impõe o dever de socorro a quem tiver tido a culpa do acidente. $E$ se fosse exata essa perspectiva, a razão estaria do lado dos que sustentam que. em um caso como no outro, decisivo é o fato de o agente se propor um fim que, segundo o seu mundo de representacões, não é ilícito; a fato de - para se falar na linguagem da culpa da personalidade - a censura se fundamentar sempre em uma deficiente posição da prsonalidade que não curou de se informar sobre as exigências do direito". ${ }^{17}$

"... quando falta ao agente o conhecimento de circunstancias tipicamente relevantes, a censura da culpa funda-se em uma falta de conhecimento ao nível da consciência-psicológica; quando existe dolo-do-fato, mas falta a consciência da ilicitude, a censura fundamenta-se com uma falta da própria consciência-ética, relacionada com os valores que ao direito penal especificamente cumpre proteger".

Muitos outros aspectos poderiam ser analisados, como aqueles que dizem respeito a não censurabilidade da falta 17. Ob. cit., g. 263-64. 
de consciência da ilicitude, do problema em relação ao erro de direito e ao erro de fato, dos aspectos formais e materiais da culpa. Mas o que se referiu basta para mostrar quão complexa e atual é a doutrina da culpa com todas as suas aporias.

Das apreciações, a grandes traços, acerca da doutrina da culpabilidade convém concluir por algumas proposições à guisa de síntese do problema.

De tudo quanto tem construído a teoria moderna da culpa, apesar de suas variacões, de suas dubiedades e por que não dizer? - de suas perplexidades, cabe precisar alguns elementos que, a meu ver, não podem faltar numa concepção de culpa sob uma perspectiva normativa e ética, se não quizermos que o direito penal seja uma simples técnica de coerção.

Além do pressuposto da imputabilidade do fato ao agente, tanto do ponto de vista material quanto psíquico, aceitado $o$ indeterminismo relativo da vontade humana, são estes os elementos integrativos do conceito:

a) o conhecimento ou cognoscibilidade da natureza da ação, do ponto de vista causal e do ponto de vista finalista;

b) o conhecimento ou cognoscibilidade do caráter ilícito do evento e, portanto, valoração dele, dentro do complexo ético-social-jurídico;

c) censurabilidade do comportamento do agente, nas circunstâncias concretas do agir humano,

d) exigibilidade do dever de adequação ao comportamento social à norma jurídica, apreciado também este requisito nas circunstâncias concretas da ação.

Voltemo-nos agora para o diploma penal de 69 , cuja promessa de vigência tem sido por mais de uma vez protelada.

Lemos no preâmbulo da Exposição de Motivos do novo Código a declaração de que, "tendo-se presente a realidade brasileira, procurou-se ajustar a nossa legislação penal às exigências fundamentais de um Direito Penal da Culpa, que visa a proscrever toda forma de responsabilidade objetiva, proporcionando-se, por outro lado, soluções eficientes para a repressão da criminalidade grave".

Apesar da enfática proclamação, não observou o legislador de 69 inteira coerência no desdobramento do princípio, quando estruturou o novo diploma.
Ao regular, no parágrafo $2^{\circ}$ do artigo 13 , a omissão como causa relevante do resultado típico, permitiu o reconhecimento de uma hipótese de responsabilidade objetiva, quando considera o simples risco criado pelo comportamento anterior, mesmo sem culpa. Nesse caso, surgiria a exigibilidade do dever de agir para evitar o resultado, não previsto nem previsível, considerando a omissão desse dever como causa da anterior atividade causadora do perigo.

Outro desvio da doutrina que considera a culpa como prevalente na solução dos problemas penais, aparece na aplicação da medida de segurança ao invés da pena aos criminosos semi-imputáveis. Segundo afirma o legislador de 69 , a substituicão se justifica porque "a pena, não obstarite a sua natureza retribuitiva, deve ser cumprida como uma medida de segurança, ou seja, tendendo à recuperação social do delinquente". Pelo mesmo motivo, o Código não mais admite as medidas de seguranca detentivas para imputáveis.

Ora, diante da própria posição do Código, faleceria a razão para que os criminosos de imputabilidadt tão só diminuída fossem subtraídos à pena.

Apaga-se, por outro lado, a distinção entre pena e medida de segurança, entre culpabilidade e perigosidade, conceitos que, à luz do Direito Penal da Culpa, são distintos consultam a finalidades diversas.

A não aplicação de sanção punitiva a esses criminosos, além de enfraquecer a própria defesa social, não atenderia à Justiça material a que tanto acena o legislador.

Ainda, outra incoerência pode ser apontada, quando se nega ao erro de direito o efeito de excluir a culpabilidade, ainda que inexigível a conduta adequada ao dever jurídico pelo não conhecimento escusável, concretamente, da ilicei dade da ação.

Salienta-se depois, na Exposição de Motivos, a fidelidade do Código ao princípio "nullum crimen sine culpa", dizendo-se que é uma das constantes do projeto e sua significação exegética não deve ser esquecida. Dando aplicação ao princípio básico da inexistência da responsabilidade sem culpa, sublinha ainda a Exposição de Motivos, "o projeto incorporou a regra hoje generalizada, de que o agente só responde pelos resultados que especialmente agravam as penas, quando os houver causado pelo menos culposamente". "Isso se aplica a todas as causas de aumento situadas no desdobramento causal da aç̃o, e, em particular, aos crimes qualificados pelo resultado". 
A enunciação da regra aludida merece louvores, pois corta pela raiz a controvérsia que se pode levantar legitimamente no campo do atual Código Penal, quanto aos resultados ocorridos no curso causal da ação voluntária, ainda que proclame a Exposição de Motivos, que sem o pressuposto do dolo e da culpa stricto sensu nenhuma pena será irrogada, e Nelson Hungria tenha terçado as armas brilhantes da sua dialética para sustentar que fora da culpa stricto sensu não se poderia imputar ao agente o resultado da vontade, ainda que tivesse, como antecedente causal, eficaz ou relevante, a ação humana.

A ausência de disposição semelhante a que consta do artigo 19 do novo Código, ensejava, pelo menos, a discussão, e permitia que alguns argumentos ponderáveis, em face da lei positiva, pudessem ser aduzidos para defender a tese que hoje não poderia prosperar perante o diploma de 69 .

Menciona, a seguir, as duas formas que pode assumir o elemento subjetivo do crime. Quanto ao dolo, reproduz a fórmula atual, em que ao critério clássico da vontade se acrescenta o da representação combinado com o do prévio assentimento ao resultado.

Quanto à culpa, não foi feliz o legislador. Além do mau gosto da redação, mal que muito enfeia o novo Código, defeituosa é a fórmula pela imprecisão e redundância. Ao invés da imprudência, negligência e imperícia que bem tradu zem a fonte psicológica da culpa e o descumprimento do dever de diligência a que está obrigado o homem no convívio social, aparecem a omissão de cautela, atenção ou diligência como determinantes causadoras da não previsão do resultado previsível, ou como causa de não haver sido evitado o resultado que poderia evitar, porque previsto nas circunstâncias em que agira o autor da culpa.

Está a sobrar do texto a qualificação da conduta do agente - como leviana - pelo fato de acreditar que o resultado não se realizaria ou poderia ser evitado.

A crença na não realização ou na evitabilidade do resultado, mercê das circunstâncias, ou mesmo a atenção ou diligência posta na execução do fato pode não ser fruto de leviandade do agente que, bem ao contrário, só teria agido por tal modo, porque, ainda que previsto o evento, confiara na sua não ocorrência, precisamente pela reflexão e cuidado postos na ação inicial desencadeadora.

Correta é a fórmula do Projeto Soler de 1960 que se oferecia ao legislador brasileiro:
"Responde por culpa el que há producido un resultado delictuoso sin quererlo, cuando por imprudencia, negligencia, imperícia o por inobservância de los deberes que en concreto le incumbiam, no previó que occurriria o, previéndolo, creyó poder evitarlo'.

\section{Ignorância da lei ou erro de direito}

O legislador de 69 atribuiu à ignorância e ao erro na interpretação da lei, o efeito de atenuar a pena ou permitir a substituicão por outra menos grave. Não lhes deu o efeito de excluir a pena, como figurava no projeto Nelson Hungria.

De logo, observa-se um defeito técnico na formulação do princípio. A escusabilidade, ou seja, a não reprovabilidade da conduta, deve referir-se tanto ao caso da ignorância quanto ao de erro. No texto apenas aparece a escusabilidade em relação à ignorância da lei.

O anteprojeto argentino, de Soler, ao qual fizera remissão o projeto de Hungria, usa de construção correta na enunciação do preceito, quando dispõe que não é culpável o agente quando se encontra na crença de obrar licitamente, devido à ignorância ou erro na apreciação da lei, desde que não lhe seja uma ou outro censurável.

Não nos parece feliz a formulação legal que não deveria omitir a referência à culpabilidade, atenuada na hipótese, para sublinhar que o problema se situa dentro da teoria da culpa, isto é, na área subjetiva. Pois a igonorância e o erro só se tornam relevantes, tanto para atenuar, como para excluir a pena, quando restringem ou impedem se constitua no agente a consciência da ilegitimidade da própria conduta.

O eminente Soler coloca o princípio no capítulo da culpabilidade, dando à ignorância e ao erro, quando escusáveis, o efeito de dirimir a culpa, e observa à margem do seu projeto:

"Si se aspira a la construción de un derecho penal cuyo nucleo está constituído por la culpabilidad y si, en consecuencia, se postula como princípio ideal el de que nadie sea sin culpa sometido a pena, no cabe duda de que el error y ignorancia de derecho quitan base de justicia a la punición. El error y la ignorancia de derecho son reconocidos como causales de inculpabilidad por Proj. Peco, projeto alemão de 1958, Código Colombiano, greigo, polaco e suizo". 
Outro reparo cabe quanto à manifestação do erro. Admite o Código que o erro provenha da interpretação da lei. Ora, a interpretação pressupõe uma tarefa eminentemente técnico-científica, inteiramente estranha ao comum dos homens.

O homem comum, profano no mundo da ciência jurídica, ao qual se dirigem as prescrições penais, não realiza essa tarefa interpretativa. Logo, o erro não poderá surgir para ele no curso da interpretação. Só ao jurista tal hipótese se poderia endereçar.

O homem comum deve ter a compreensão não deste ou daquele artigo da lei penal, mas das valorações sociais em que o seu comportamento implica, e só assim se aceita a existência de uma consciência ética sobre a liceidade ou iliceidade das acões humanas. É no curso desta apreciação acerca dos valores ético-juridicos recolhidos pela lei que ele poderá razoavelmente ser conduzido ao erro.

E assim se justifica que o conhecimento suposto e exigido pelo dolo, observa Jorge Figueiredo Dias, se refira aquele sentido prático-social antes que a estes pressupostos materiais e jurídicos: $\mathrm{E}$ acrescenta:

"O exemplo mais utilizado, por muito característico, na ilustração deste grupo de elementos é o do caráter "alheio" da coisa no crime de furto (art. 421: coisa "que não lhe pertenca"). Trata-sie aqui, efotivamente, de uma qualificação normativa que, implicando embora uma decisão eminentemente jurídica, é todavia - ao contrário do que sucede com a "ilegitimiảade" da intenção de apropriação passível de traducão imediata no plano prático-social dos sentidos da vida-corrente, entre os quais se encontra seguramente o de uma certa coisa estar fora do domínio patrimonial de uma pessoa".

"Doutrina que vale paralelamente para uma extensa série de elementos normativos que, quanto à determinação do dolo, revelam essencialmente a mesma estrutura - como será o caso de elementos como "Governo', "Estado" e "Pátria" (art. 141 ss.) " "tribunal" (v.g. art. 181, § 2), "ma trimônio" (art. 337), "adultério" (art. 401), "coisa que lhe pertença', "coisa penhorada", "coisa depositada" (arts. 422 e 424), etc". ${ }^{18}$

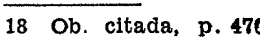

\section{Erro de fato}

Quanto ao erro de fato apenas preferiríamos que, ao invés da referência à isenção de pena, se declarasse não cul pável o agente que a tal situação fosse conduzido pela erronea apreciação sobre o fato que constitui delito ou sobre as circunstâncias que excluiriam a injuricidade.

\section{Coação Irresistível}

Relativamente ao problema da coação irresistível, o legislador de 69 começa por distinguir a coação física da coa ção moral.

Só a última - a coação moral - é propriamente causa da inculpabilidade.

$\mathrm{Na}$ coação física, agindo o violentado como simples corpo (corpo de que se poderia dizer que teria perdido a alma), não há falar em inculpabilidade .Trata-se, como salienta Soler, de um caso típico de não ação, em que não existe um mínimo de participação subjetiva. É no terreno da causalidade material ou nexo causal objetivo que o problema se resolve, considerando-se a passividade a que foi reduzido o coato como não causa em relação ao resultado. A causa se encontra exclusivamente na ação do coator que é único agente do delito.

$\mathrm{Na}$ coação moral, porém, ao coagido se oferece, pelo menos, in abstracto, a possibilidade de resistir ou de ceder à ameaça. Há sempre a preceđência da vontade, ainda que esta venha a sucumbir depois pela ameaça. A culpabilidade é ilidida pela inexigibilidade de outra conduta, que deve ser apreciada em concreto e tomando-se como referência o homem comum, não o herói ou o santo.

\section{Obediência hierárquica}

A obediência hierárquica com a coação moral aparece no mesmo artigo.

Há de compreender-se a obediência hierárquica como resultado da violência exercida pelo superior ao dar a ordem ilegal ao subordinado que tem a obrigação jurídica de cumprir a ordem.

A coação moral e a obediência hierárquica são, ambas, referíveis ao princípio da inexigibilidade de outra conduta. 


\section{Estado de necessidade}

O estado de necessidade é previsto no novo Código como causa da inculpabilidade (art. 25) e como causa de exclusão de crime (art. 28).

Na modalidade com que se apresenta como causa de inculpabilidade, o estado de necessidade se filia também ao princípio da inexigibilidade de outra conduta.

A situação de perigo que envolve o agente e o colega na contingência de sacrificar o direito alheio, para salvaguarda do próprio, afasta a culpa pela necessidade a que o agente não pudera resistir.

De enorme riqueza de perspectivas é o princípio da inexigibilidade de conduta diversa àquela a que estava obrigado in abstracto o agente pelo dever que deveria estar presente em sua consciência ética. A necessidade inelutável tolhe o dever jurídico que lhe importa o respeito ao direito alheio, e, consequentemente, a culpa.

O princípio da inexigibilidade de outra conduta é, segundo a sutil interpretacãa de Ruy Cirne Lima, a manifestação da misericórdia a temperar de doçura e benevolência a justiça, é a compreenção da fragilidade humana a que se não pode, em certas circunstâncias, exigir resista à lei da necessidade.

Pelo aludido princípio de que Cícero já se ocupava (Inventione, $2,57,2)$ e que no direito canônico tolhe o delito quando o agente pratica a acão para afastar grave incômodo, abona-se a ilicitude da conduta realizada, ainda que contrastante, objetivamente, da norma penal, absolvendo-se, o agente, do juízo da censurabilidade.

Mostra o Professor Ruy Cirne Lima, em admirável ensaio, que o princípio tem a sua fonte na filosofia estóica $e$ que Cícero, acerca da necessidade, à qual nenhuma força pode resistir (cui nulla vi resisti potest), nos diz que ela abrange a preservação da honra (honestas) da incolumidade, a essa próxima, e, como última, a levíssima da comodidade (De Inventione, 2, 58, 1-4). "A incolumidade realmente compreende, pode dizer-se, a honra, já que sem aquela não poderíamos nunca entrar a fruir desta, "quoniam sine incolumitate seam nulo tempore possumus adispisci" (De Inventione, 2, 58, 17-17). Nem por isso a comodidade há de ser totalmente ignorada. Necessária é, ela, também, se desejamos viver sem incômodo: "necesse est si sine incommodo volumus vivere" (De Inventione, $2,27,51,52$ ). Vale observar-se, enfim, que, em qualquer hipótese, hão de ser apreciados os fatos, não segundo a natureza desses, senão segundo o tempo e o propósito, "ex tempore et ex consilio" (De Inventione, 2, 58, 39-40).

Eis aí algumas observações e alguns dados pertinentes a um tema que constitui a polpa viva de outro princípio básico, que é a responsabilidade penal, e, portanto, nele se desenha a linha medular ou axial de todo o sistema jurídico dos crimes e das penas.

Se não quisermos voltar aos dias sombrios de um direito penal totalitário, deveremos insistir pela preponderância do direito penal da culpa, ao invés do direito penal do fato, pois só assim colocaremos no centro e no fundamento a eminência e a transcendência da pessoa, pois só em relação a ela, antes e sobre o Estado, os valores encarnam-se e ganham significado no mundo histórico e social.

No belo volume publicado em homenagem a Luís Jimenez de Asúa, Giuseppe Bettiol colabora com o estudo "Sobre las ideas de culpabilidad en un derecho penal moderno".

Lemos em Bettiol ${ }^{10}$ este conceito com o qual podemos encerrar este trabalho:

"O Direito Penal pertence a esta categoria de ciências denominadas morais, onde não impera o ser senão o dever-ser. E a culpabilidade é, portanto, um juízo de que se serve o Direito Penal para poder explicar as coisas que correspondem à sua experiência cultural". 